\title{
ЕЛЕКТРОННИЙ РЕСУРС «ВИДАТНІ ПЕДАГОГИ УКРАЇНИ ТА СВІТУ» Й ОНЛАЙН-ПРОЕКТ «МИ СТОÏМО НА ПЛЕЧАХ НАШИХ ПОПЕРЕДНИКІВ: ВИДАТНІ ПЕДАГОГИ-ЮВІЛЯРИ»
}

https://doi.org/10.37472/2707-305X-2020-2-1-7-4

\section{БEРEЗІBCbKA}

Лариса Дмитрівна

доктор педагогічних

наук, професор, член-

кореспондент НАПН

України, директор

Державної науково-

педагогічної бібліотеки

України імені

B.О. Сухомлинського,

Національна академія

педагогічних наук України,

м. Київ, Україна

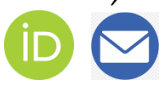

\section{ДЕРЕВЯНКО}

\section{Тетяна Михайлівна} науковий співробітник відділу педагогічного джерелознавства та біографрістики Державної науково-педагогічної бібліотеки України імені В.О. Сухомлинського, Національна академія педагогічних наук України, м. Київ, Україна

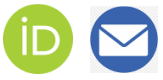

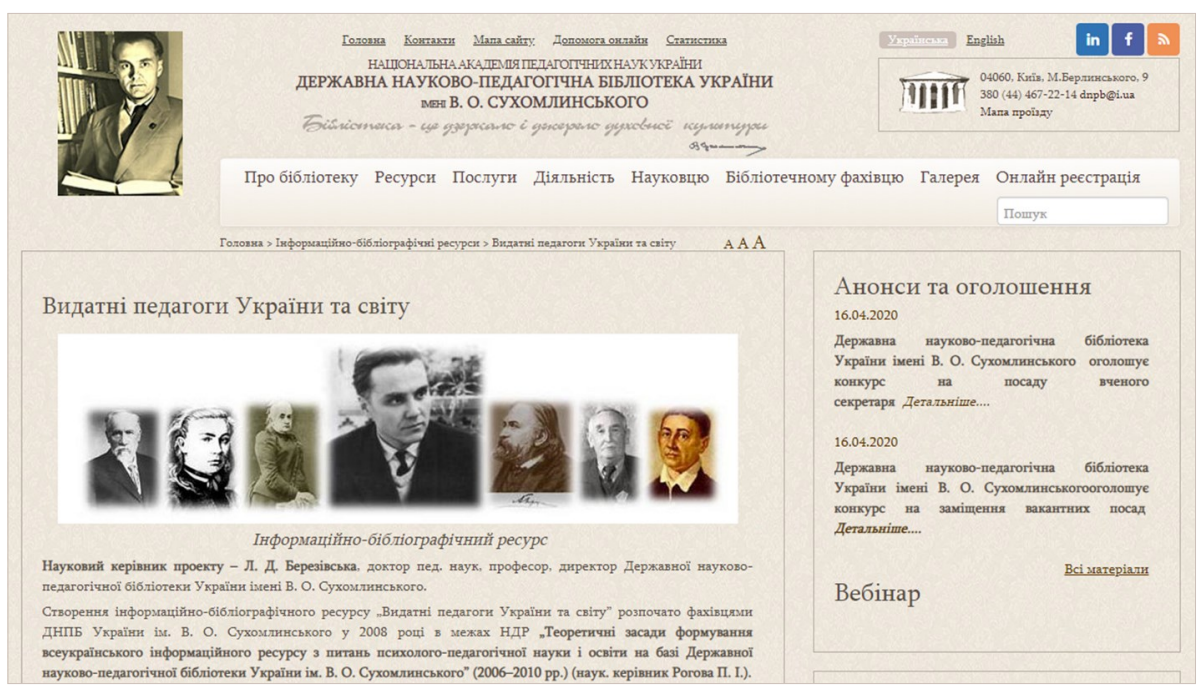

Анотація. У статmі розкрито зміст і роль створеного Державною науково-педагогічною бібліотекою України імені В.О.Сухомлинського електронного інформачійно-бібліографрічного ресурсу "Видатні педагоги України та світу» для розвитку й поширення педагогічного біографічного знання в Україні. Зазначено, що нині постійно поповнюваний електронний ресурс містить відомості про 56 відомих вітчизняних та зарубіжних педагогів, освітніх діячів різних історичних періодів. Аргументовано, що електронний інформачійно-бібліографічний ресурс "Видатні педагоги України та світу» дає змогу крізь призму біографрій знаних педагогічних персоналій системно простежувати розвиток української та зарубіжної освіти, педагогічної думки як у макроісторичних, так і в мікроісторичних вимірах. Презентовано онлайн-проєкт «Ми стоїмо на плечах наших попередників: Видатні педагоги-ювіляри», розроблений відділом педагогічного джерелознавства та біографрістики ДНПБ України імені В.О. Сухомлинського на базі иього електронного ресурсу. Висвітлено його зміст і значення для широкого кола користувачів бібліотеки, зокрема освітян та науковців. Окреслено подальші напрями розвитку онлайнпроєкту.

Ключові слова: педагогічна біографіка; електронні ресурси; інформаційнобібліографічні ресурси; електронний інформачійно-бібліографічний ресурс «Видатні педагоги України та світу»; онлайн-проєкт.

Провідну роль в інтеграції та поширенні педагогічного біографічного знання в Україні відіграє Державна науково-педагогічна бібліотека України імені В.О. Сухомлинського (далі - ДНПБ). На веб-порталі ДНПБ представлено електронний інформаційно-бібліографічний ресурс «Видатні педагоги України та світу», що розробляється фахівцями в межах наукових досліджень (2008-2014рр. - керівник П.І. Рогова, із 2015 р. - Л.Д. Березівська). 
Нині зазначений ресурс, який постійно доповнюється та оновлюється, містить 56 персоналій. Це відомі вітчизняні педагоги та освітяни різних історичних періодів розвитку освіти:

- Х.Д. Алчевська

- Т.Г. Лубенець

- C.A. Ананьїн

- А.С. Макаренко

- О.М. Астряб

- О.Ф. Музиченко

- С.Я. Батишев

- В.П. Науменко

- Є.С. Березняк

- М.Ф. Берлинський

- Т.Ф. Бугайко

- М.Х. Бунге

- Г.Г. Ващенко

- М.М. Грищенко

- Б.Д. Грінченко

- М.М. Грінченко

- М.І. Демков

- Л.Д. Деполович

- М.П. Драгоманов

- В.Ф. Дурдуківський

- О.В. Духнович

- Г.Є. Жураківський

- O.A. Захаренко

- В.Н. Каразін

- M.O. Корф

- Г.С. Костюк

- П.О. Куліш

- М.M. Ланге

- В.О. Онищук

- Олена Пчілка

- М.І. Пирогов

- Я.Б. Рєзнік

- С.Ф. Русова

- Я.П. Ряппо

- І.О. Сікорський

- Г.С. Сковорода

- І.П. Соколянський

- І.М. Стешенко

- В.О. Сухомлинський

- І.Ф. Тесленко

- К.Д. Ушинський

- С.Х. Чавдаров

- П.Р. Чамата

- Я.Ф. Чепіга

(Зеленкевич)

- П.Д. Юркевич

- М.Д. Ярмаченко

Крім того, у ньому представлено й зарубіжні персоналії:

- В.М. Бехтерєв

- Ф. Діттес

- M. Монтессорі

- Г. Кершенштейнер

- Ж.-Ж. Руссо

- Я.А. Коменський

- Ф.В. Фребель

- Я. Корчак

Електронний інформаційно-бібліографічний ресурс «Видатні педагоги України та світу» системно презентує для освітянської громадськості:

- біографію діяча;

- бібліографію його праць і матеріалів про нього;

- окремі повнотекстові твори;

- додаткові матеріали, зокрема фотогалерею;

- відомості, що розкривають діяльність установи, яка носить його ім'я (за наявності);

- інформацію про нагороди, премії, пам'ятники, наукові читання, пов'язані з ім'ям видатної постаті тощо.

Важливо, що робота над сторінкою кожної персоналії електронного ресурсу триває безперервно.
Зазначимо, що крізь призму біографій педагогів та освітніх діячів простежується розвиток української освіти, гуманістичної педагогічної думки як у макроісторичних, так і в мікроісторичних вимірах. Прикметно, що інформаційнобібліографічний ресурс «Видатні педагоги України та світу» цілісно представляє життєвий шлях і науковий доробок певної відомої постаті й відображає ступінь ї̈ дослідженості в науковому просторі, а це сприяє поглибленню інформаційних запитів віддалених користувачів, зокрема науковців, викладачів, студентів, аспірантів, докторантів України та світу, із різноманітних проблем історії національної й зарубіжної освіти (Березівська, 2019). Водночас він забезпечує інформаційний супровід історико-педагогічної науки, бо є джерелом для написання дисертацій, наукових досліджень, бакалаврських і магістерських робіт; сприяє наповненню змісту підручників з історії освіти та педагогіки; уможливлює якісне проведення масових науково-практичних заходів (конференцій, круглих столів тощо), присвячених творчій діяльності тих чи інших педагогів й освітніх діячів. Крім того, ресурс ознайомлює дослідників із фондом ДНПБ, зокрема з педагогічними джерелами.

Сьогодні це один із найбільш затребуваних електронних ресурсів ДНПБ, про що свідчать відповідні статистичні дані (станом на квітень 2020 р. - 2439 переглядів; 2019 р. - 1510; 2018 р. - 829). Причому, як бачимо, його популярність зростає з кожним роком.

Саме він став основою онлайн-проєкту «Ми стоїмо на плечах наших попередників: видатні педагоги-ювіляри», започаткованого в квітні 2020 р. відділом педагогічного джерелознавства та біографістики в межах виконання наукового дослідження «Педагогічна наука та освіта в

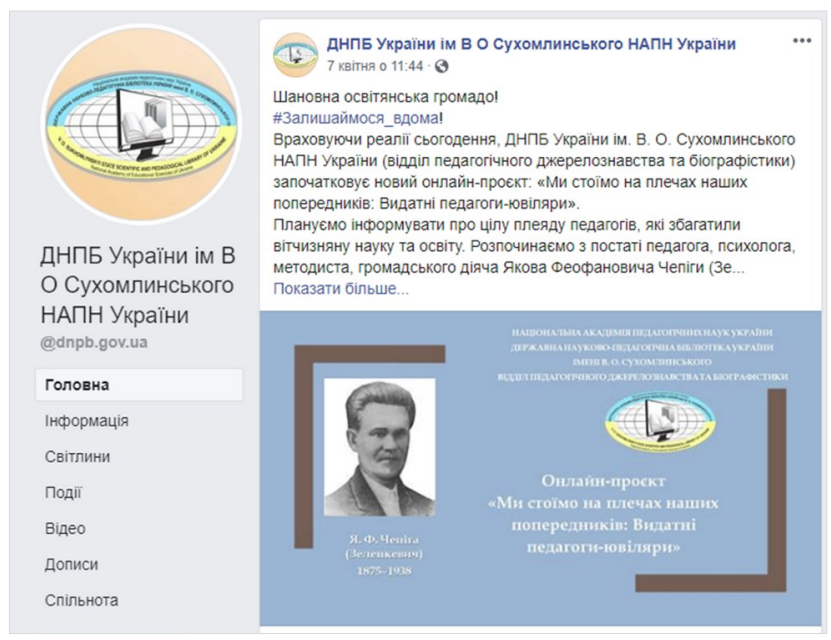


особах, документах, бібліографії» (2020-2022 рр., керівник - Л.Д. Березівська). у рамках проєкту на офіційній сторінці ДНПБ у Facebook користувачам надається посилання на повний текст однієї із праць відомого представника педагогічної науки, з якою вони можуть ознайомитись онлайн і залишити свої враження від прочитаного в коментарях. Розпочали його з постаті знаного українського педагога, психолога, громадського діяча Я.Ф. Чепіги (Зеленкевича) (1875-1938), 145річчя від дня народження якого освітянська громада святкуватиме 12 травня цього року. Позитивно, що до прочитання педагогічних праць Я.Ф.Чепіги долучаються наукові та науковопедагогічні працівники, студенти педагогічних закладів вищої освіти - майбутні педагоги.

Серед ювілярів 2020 р. - відомий український педагог, фахівець із питань дидактики та методики О.Ф. Музиченко, видатний італійський педагог, лікар М. Монтессорі та ін. Співробітники відділу педагогічного джерелознавства та біографістики ДНПБ оновлюють інформацію про ці персоналії, добирають праці для онлайн-прочитання. Проєкт триває.

\section{СПИСОК ВИКОРИСТАНИХ ДЖЕРЕЛ}

Березівська, Л.Д. (2019). Електронний інформаційнобібліографічний ресурс «Видатні педагоги України та світу» як основа професійної підготовки педагогів. In В.Г. Кремень, В.П. Коцур, Н.Г. Ничкало, Ф. Шльосек, С.О. Довгий, Л.Б. Лук'янова, М.П. Вовк, К.В. Котун (ред.), Освіта для миру = Edukacja dla pokoju (c. 222-228). Т. 2. Київ: Видавництво ТОВ «Юрка Любченка». https://lib.iitta.gov.ua/717478/
Svitlana Hopta Ця праця Я. Чепіги має стати настільною для батьків всієї України.. "Для виховання дитини мало бути батьком, мати право сильного... Треба мати щире серце, ясний розум і моральну висоту. Мета сім'ї - виховання дитини: вона повинна й би вільно нормативно и гармонійно..." (Я. Чепіга)

Подобається - Відповісти - 2 тиж.

Ксения Пономаренко Прочитавши працю Якова Феофановича Чепіги " Моральне внушіння у справі виховання " я підкреслила для себе багато нового про виховання дитини. Погоджуюсь 3 його поглядами щодо єдності батька та матері у вихованні дитини:" Батько мати для дитини неподіль.

Переглянути більше

Подобається - Відповісти - 3 дн.

Anya Makarenko Праця Я.Чепіги дуже гарна,я не шкодую щுо прочитала цю працю.Все дуже чітко розповідається і зрозуміло.Мати - це «цілий світ навчань».. Глибоко правдиві слова Пирогова:

«Доглядаючи ще з колиски за людиною, дбаючи про розвагу дитинства,

навчаючи ї уста ... Переглянути більше

Подобається - Відповісти - 1 тиж. - Відредаговано

Анна Грибань "Мати та їі вчинки - це те чарівне коло переймання всяких почуттів, від яких дитина дорослою не може відірватися. Вона не може

зробити жодного значного вчинку, щоб неї не відбивались не відгукувались так або інакше ідеї почуття матернього впливу. Од ма... Переглянути більше

Подобається · Відповісти - 1 тиж.

Sevkus Burkus B тексті добре описано вразливість дитини, ї беззахисність перед світом. Хотілось би, щоб педагог в образі вчителя чи батьків виступав дитині провідником, захисником i тренером для життя в дорослому суворому світі.

"Щоб дати дитині потрібний нормальн... Переглянути більше Подобається - Відповісти - 1 тиж.

Державна науково-педагогічна бібліотека України імені В.O. Сухомлинського (n.d.). Головна [Facebook сторінка]. https://www.facebook.com/dnpb.gov.ua/

Електронний інформачійно-бібліографічний ресурс «Видатні педагоги України та світу» (n.d.). http:// dnpb.gov.ua/ua/інформаційно-бібліографічніресурси/видатні-педагоги/

\section{ELECTRONIC RESOURCE "PROMINENT UKRAINIAN AND WORLD EDUCATORS” AND ONLINE PROJECT "WE ARE STANDING ON THE SHOULDERS OF OUR PREDECESSORS: PROMINENT EDUCATORS WHOSE JUBILEE IS BEING CELEBRATED”}

\section{Larysa Berezivska \\ DSc in Pedagogy, Professor, Corresponding Member of NAES of Ukraine, Director, V.O. Sukhomlynskyi State} Scientific and Pedagogical Library of Ukraine, National Academy of Educational Sciences of Ukraine, Kyiv, Ukraine Tetyana Derevyanko

Research Fellow of the Department of Pedagogical Source and Biography Studies, V.O. Sukhomlynskyi State Scientific and Pedagogical Library of Ukraine, National Academy of Educational Sciences of Ukraine, Kyiv, Ukraine

Abstract. The article reveals the contents and the role of the electronic information and bibliographic resource "Prominent Ukrainian and World Educators" created by V.O. Sukhomlynskyi State Scientific and Pedagogical Library of Ukraine for the development and dissemination of pedagogical biographical knowledge in Ukraine. At present a constantly replenished electronic resource contains information about 56 well-known Ukrainian and foreign educators, educational figures of different historical periods of education development. The electronic information and bibliographic resource "Prominent Ukrainian and World Educators" makes it possible, through the prism of biographies of well-known pedagogical personalities, to monitor systematically the development of Ukrainian and foreign education, pedagogical thought both in macrohistorical and microhistorical dimensions. The online project "We are standing on the shoulders of our predecessors: prominent educators whose jubilee is being celebrated" designed by the Department of Pedagogical Source and Biography Studies of V.O. Sukhomlynskyi State Scientific and Pedagogical Library of Ukraine on the basis of the mentioned electronic resource is presented. Its contents and significance for a wide range of library users, in particular for educators and scientists, is specified. Further directions for the development of the online project is outlined.

Keywords: pedagogical biographics; electronic resources; information and bibliographic resources; information and bibliographic resource "Prominent Ukrainian and World Educators"; online project. 